\title{
Airport Pricing of Aircraft Takeoff and Landing Slots: An Economic Critique of Federal Regulatory Policy
}

\author{
Daniel R. Polsbyị
}

American airports have become increasingly congested over the last generation. Air travel delays, which cost the economy countless amounts in lost productivity and frustration, are accelerating at an alarming rate. This Comment argues that one can trace part of the congestion problem to a flawed system of airport slot pricing. Bolstered by outdated federal regulatory policy, this system discourages airports from charging aircraft for the full opportunity costs they impose on other airport users. The Comment critiques current federal regulatory policy on airport pricing and recommends new policy to alleviate airport congestion. Specifically, it advocates opportunity cost pricing of airport resources and peak time pricing of slots to mitigate airport congestion and yield a fairer, more efficient air travel system.

"To measure the heartbeat of your city, take the pulse of its airport."

Billy Mitchell ${ }^{1}$

\footnotetext{
Copyright $\odot 2001$ California Law Review, Inc. California Law Review, Inc. (CLR) is a California nonprofit corporation. CLR and the authors are solely responsible for the content of their publications.

$\dagger \quad$ J.D. Candidate, May 2001, School of Law, University of California, Berkeley (Boalt Hall); B.A., Oxford University, 1998; B.A., Yale University, 1996. 1 would like to thank Samuel B. Thompson and Howard A. Shelanski for reading drafts and offering many helpful suggestions. I also want to thank the members and editors of the California Law Review for their help with this Comment, especially Jen Polse and James Oleson. To Edward H. Clarke, 1 owe a large debt for introducing me to the topic of airport pricing, commenting on several drafts of the paper, and acting as an endless fountain of airport literature and guidance. I dedicate this Comment to my family for their love and support.

1. Billy Mitchell, 1929 cited in Lawrence J. Truitt, Alleviating Airport Congestion Crisis in Westem Cities through the Wayport Concept 1 (Mar. 27, 1990) (unpublished manuscript, on file with University of California, Berkeley, Institute of Transportation Studies Library).
} 


\section{INTRODUCTION}

In July of 1968, congestion reached a new peak at several large hub airports in New York, Washington, D.C., and Chicago. Planes were queued on the ground or stacked in the skies with waits routinely reaching two hours. These delays reduced travel safety, imposed huge costs on passengers and airlines in terms of time wasted, and reduced public confidence in the nation's air transportation system. In calling for a solution to airport congestion in the late 1980s, Secretary of Transportation Samuel Skinner called America's congested airport infrastructure a "national embarrassment."2 And a month before leaving office, President Clinton noted that while our air travel infrastructure has inade progress, "as horrendous-and I don't know how else to say it-just the horrendous flight delay statistics demonstrate, we have not done nearly enough."'3

Today, congestion continues to plague many of the nation's largest airports, imposing significant costs on carriers and passengers. The Federal Aviation Administration ("FAA") has estimated that additional time costs to passengers and additional operating costs to carriers amount to over $\$ 5$ billion annually. ${ }^{4}$ Given the development of hub-and-spoke operations and the increase in air travel, the FAA has predicted that soon, nearly sixty airports could require some type of limitations in access due to congestion. ${ }^{5}$ Indeed, the problem may have accelerated beyond the FAA's projections. One study shows that flight delays for the first eight months of 1999 rose to a national total of 265,200 delays of more than fifteen minutes. This figure represents a rise of nearly $20 \%$ over the same period a year earlier. ${ }^{6}$ Moreover, flight delays are not a phenomenon umique to the United States. Throughout Europe and Asia the boom in air traffic has increased concern over air congestion. ${ }^{7}$

Commentators spread the blame for air traffic delays broadly. They target outdated air traffic control systems, inadequate numbers of air traffic

2. Richard G. O'Lone, Major Coordinated Effort Required to Avoid Global Airport Congestion, Aviation WK. \& Space Tech., Nov. 20, 1989, at 54. Jane Garvey, the prior Administrator of the Federal Aviation Administration ("FAA"), has told the House Transportation Committee that "[t]he FAA is willing to do whatever is within our power to improve the efficiency of the air traffic system, so long as safety is not compromised." Flights Will be Late More Often if FAA Doesn't Act, Airlines Warn, S.F. CHRON, Oct. 15, 1999, at A12.

3. Remarks by the President in FAA Announcement, Dec. 7, 2000, at 1.

4. Steven A. Morrison \& Clifford Winston, Enhancing the Performance of the Deregulated Air Transportation System, in Brookings PAPERs on Economic Activity: Microeconomics 1989 61, 84 (Martin Neil Baily \& Clifford Winston eds., 1989).

5. Hub and Spoke is an air transportation system by which passengers take local flights to a large hub airport where they can take long-distance or other local flights to their final destinations. William G. Laffer 1II, How to Improve Air Travel in America, Heritage Foundation BACKGROUNDER, Jan. 25, 1991, at 5. B3.

6. Matthew L. Wald, Aviation Experts Bemoan Delays in the $S k y$, N.Y. Times, Sept. 29, 1999, at

7. See O'Lone, supra note 2 , at 54 . 
controllers, insufficient runway space, and increased passenger travel as some of the sources of airport torpor. ${ }^{8}$ Given how analysts frame the source of airport congestion, recommended solutions include hiring more air traffic controllers, spending more on updating air traffic equipment, building more runways, and funding more airports. ${ }^{9}$ In sum, most commentators seek to coinbat overcrowded airports by increasing investment in airport resources.

In contrast to the popular approach of solving airport congestion by expanding airport resources, this Comment argues that existing resources should be allocated more efficiently. In particular, it argues that current federal regulatory policy impairs more efficient use of airport resources by effectively restricting the fees airports can charge aircraft for takeoff and landing slots. ${ }^{10}$ This Comment first critiques current federal pricing policy and then proposes new federal regulatory policy on airport pricing which would allow airports to better address the costs aircraft impose on airports. Specifically, it advocates the adoption of new regulations that would encourage airports to charge nore for their opportunity costs. ${ }^{11}$

The current system for airport resource allocation has two characteristics that encourage waste of resources: first coine, first served slot allocation and weight-based pricing. ${ }^{12}$ Most airports allow aircraft to line up for the use of an airport, with aircraft that are earlier in line getting preference over those later in line ("first coine, first served"). Once aircraft depart or land, the airport then levies a charge on airport use proportional to the weight of the aircraft. This system encourages inefficient use of airport resources in several ways. First, aircraft operators, who place different values on airport resources, cannot differentiate themselves by indicating the price they are willing to pay to use the airport. ${ }^{13}$ Compare, for instance, a recreational general aviation flyer ("Rec") with a business traveler ("Biz"). ${ }^{14}$ Assume that $R e c$ has decided to land at airport (" $A$ ") to pick up a donut. Meanwhile, assume that Biz hopes to land at the same airport at the same time in order to close a time-sensitive, multi-billion dollar, business transaction. Given the current first come, first served landing slot allocation

8. See, e.g., Elmar Giemulla \& Ronald Schmid, Who Owns the Time? Legal Problems Regarding Slots-A German View, 17 AIR \& SPACE L. 9 (1992); O'Lone, supra note 2, at 54.

9. See, e.g., Wald, supra note 6.

10. Currently, nearly all airports charge for landings but do not impose an additional fee for takeofîs. See Laffer, supra note 5 , at 4 n. 4 .

11. This Comment draws much of its underlying argument and background from a seminal article on airport pricing by Michael E. Levine written more than thirty years ago. This Comment takes a different approach than the Levine piece in analyzing federal regulatory policy on airport pricing. Like Levine's article, this Comment argues for congestion charges, but goes further by advocating opportunity-cost valuation of airport land.

12. Michael E. Levine, Landing Fees and the Airport Congestion Problem, 12 J.L. \& EcoN. 79, 90-95 (1969).

13. Id. at $90-91$.

14. Id. Author's example has been modified herein. 
method, so long as Rec gets in line to land before $B i z, \operatorname{Rec}$ could delay $B i z$ in the air. This outcome is true regardless of whether Biz places a much higher value on the same landing slot. Even if it were Biz who desired to drop in for a donut and $R e c$ who valued the landing slot more highly, the point remains that there should be some way to differentiate among aircraft which place differing values on the use of scarce airport resources.

A second problem with weight-based pricing is that it provides aircraft operators with inadequate incentives to run fewer and fuller flights. ${ }^{15}$ From a pure cost perspective, it is generally cheaper to fly one full flight than two half-full flights. Under the current cost structure, aircraft operators pay for their takeoff and landing slots by the weight of the aircraft alone. And, one full flight will weigh much less than the sum of two half-full flights. But since frequent scheduling of short-haul routes yields such large competitive advantages, under the current pricing system aircraft have inadequate incentives to run fewer and fuller flights. ${ }^{16}$

Third, weight-based pricing mechanisms provide no incentives for aircraft to favor less-demanded times of the day or less-busy days of the week. ${ }^{17}$ During highly congested hours or days, aircraft operators face no higher takeoff and landing fees than during off-peak times. Though some operators may choose, for independent reasons, to shift their airport use to less congested airports, ${ }^{18}$ airports do not use takeoff and landing fees to encourage more uniform airport use. Consequently, aircraft operators who place a low value on using a given peak-time air slot may displace higher value users. ${ }^{19}$

Finally, the current flat rate system provides no opportunity for long-haul passengers, who may have no other substitute mode of transportation, to price ahead of lower value, short-haul passengers, who may have viable alternatives. ${ }^{20}$ When an airport becomes congested, fairness and efficiency would be better served if airports employed some method to identify the value placed on use by all aircraft and used this information to arrange the queue, prioritizing higher value.

Revising the existing regulatory structure to encourage airports to align their slot pricing with costs aircraft impose on them would yield several benefits. First, by allowing airport operators to price services and assets according to their incurred costs, aircraft operators would have

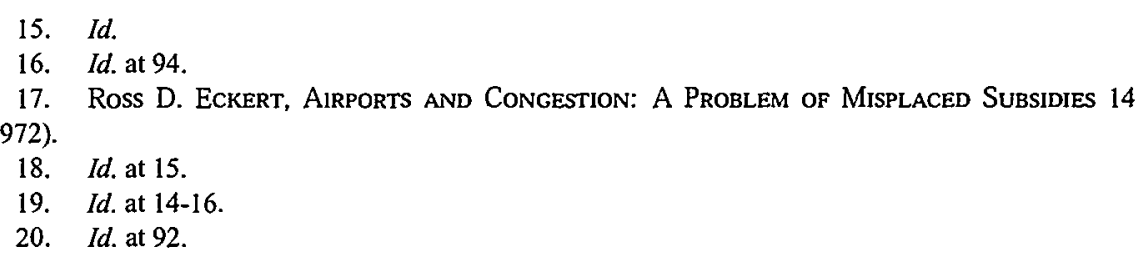


greater incentive to reduce those costs, ${ }^{21}$ and airports would allocate their scarce resources more efficiently. More efficient use of existing airport resources mitigates the demand for expanding the airport system at taxpayers' expense..$^{22}$ Funds generated directly from aircraft use of airports could be applied toward airport improvement and expansion, in lieu of general tax funding. Second, current aircraft operators would benefit from reduced congestion costs, as airlines would charge higher prices for flights that impose higher social costs. ${ }^{23}$ If costlier flights were identified by higher prices, users who place the highest value on flying at peak times would be able to purchase peak time airport use and suffer less congestion. Meanwhile, users unwilling to pay the higher prices for peak-time flights would shift their airport use to off-peak times. ${ }^{24}$ Overall, resources would be more efficiently and fairly distributed.

The Comment is structured as follows: Part I details the widespread problems of airport congestion, contending that inefficiencies from delays and overcrowding are accelerating at an alarming rate. Part II discusses how airport slot allocation fits into the economics of the airport and explores typical pricing methods as well as airport cost and revenue sources. In Part III, the Comment assesses the competing economic models behind the charges that airports levy. Part IV sets forth the federal statutes that are the basis for federal regulatory policy on airport slot pricing. In Part V, the Comment describes and critiques federal regulatory policy that has constrained pricing to historic cost methods of airport resource valuation and discouraged congestion pricing. Part V.A argues for a new approach to federal regulatory policy that encourages opportunity-cost valuation of airport resources. The Comment uses a recent case involving Los Angeles International Airport to illustrate the problems with historic cost valuation and the benefits of using an opportunity-cost methodology. In Part V.B, the Comment explores the extent to which federal regulatory policy, set out in a Logan Airport decision, discourages peak-period pricing. The Comment argues that higher pricing during peak hours will yield significant congestion reduction. Part V.C elaborates upon the potential difficulties of allowing opportunity-cost recovery in a monopoly environment and proposes a cap on airport fees during off-peak hours. ${ }^{25}$ Finally, Part VI ties the above

21. See Levine, supra note 12 , at $91-94$. These costs include wear on runways, congestion costs, and so forth.

22. See id. at 99 .

23. See id. at 102-08. This outcome rests on the assumption that airports charge airlines more for peak-time prices and that airlines pass on higher overhead costs in the form of higher ticket prices. Alternatively, if airlines chose not to raise ticket prices during peak times, the higher costs they face will give them incentive to run fewer, and fuller, peak-time flights.

24. See id. at 103-05.

25. Michael E. Levine suggested this approach to me. Email from Michael E. Levine to Daniel R. Polsby (Oct. 30, 1999) (on file with author). 
recommendations together to show how they yield a more efficient, safer, and fairer airport system.

\section{I}

\section{The Problem of Airport Congestion}

As the economy has grown to global proportions, so too have demands on transportation resources. With the rise of the airline industry, travel to all parts of the world has become not only possible, but easy and inexpensive. Yet the boom in air travel has not proceeded trouble-free. Rather, airport congestion has emerged as a new and pressing issue throughout the world. Airports in France, Germany, the United Kingdom, Japan, Hong Kong, and others, have recently encountered demand for airport resources outstripping supply. ${ }^{26}$ Indeed, by the end of this year, studies predict that at least two dozen major European airports ${ }^{27}$ and more than half a dozen major Asian Pacific Rim airports will be without adequate runway capacity. ${ }^{28}$

Closer to home, the problem has been no less severe. With a booming economy, large domestic airports have encountered similar problems of excess demand. Air traffic takeoff delays, defined as any flight that requires more than fifteen minutes to takeoff after leaving the gate, is a steadily worsening problem. ${ }^{29}$ Delays rose 63\% in September 1999 over September $1998 .^{30}$ September's figures represent an increase of $26 \%$ over the average number of delays from June through August of $1999 . .^{31}$ And from April through August of 1999 , delays rose $36 \% .{ }^{32}$ The data show that these delays are not limited to short inconveniences. To provide only one example, the FAA recently concluded that average delays for many afternoon flights at La Guardia in September 2000 exceeded 48 minutes. The average delay for all flights in that month was 43 minutes. And some flights at La Guardia experienced ground delay longer than the scheduled flight time. ${ }^{33}$ Meanwhile, over the last five years, the number of cancelled

26. E.g., R. Doganis et al., Interaction of Airport Congestion and Supply and Demand, in Longer Term Issues in Transport: The Proceedings of a Research Conference Sponsored by the Department of Transportation 192, 193-95 (J.H. Rickard \& J. Larkinson eds., 1991).

27. Id. at 194.

28. O'Lone, supra note 2, at 54.

29. Danielle Reed, Takeoffs and Landings, WALL ST. J., Nov. 12, 1999, at W8. Delays rose 63\% in September 1999 over September 1998. Id. September's figures represent an increase of $26 \%$ over the average number of delays from June through August of 1999. Id. And from April through August of 1999, delays rose 36\%. Flights Will be Late More Often if FAA Doesn't Act, Airlines Warn, supra note 2; Matthew L. Wald, F.A.A. Plans to Consult Airlines on Avoiding Traffic Delays, N.Y. TIMEs, Mar. 10,2000 , at A17.

30. Danielle Reed, Air Traffic Jam Just Gets Worse, Wal. St. J., Nov. 12, 1999, at W8.

31. Id.

32. Flights Will be Late More Often if FAA Doesn't Act, Airlines Warn, supra note 2; Matthew L. Wald, F.A.A. to Consult Airlines on Avoiding Traffic Delays, N.Y. TimEs, Mar. 10, 2000, at A13.

33. 65 Fed. Reg. 75,765 , Dec. $4,2000$. 
flights in the nation has increased by $68 \%{ }^{34}$ Experts do not predict that these problems will dissipate. On the contrary, experts, expecting travel by air to skyrocket, project an increase in airport usage of $43 \%$ by 2008 , causing a $250 \%$ rise in delays over current levels. ${ }^{35}$

Measures of societal loss from airport congestion in 1998 show that delays cost United States airlines and consumers more than four billion dollars. ${ }^{36}$ They also indicate that over 100,000 people were delayed each day of $1998 .{ }^{37}$ Though many large United States airports experience congestion, it is hard to quantify the consequent consumer and business losses. Several complexities confront one who seeks to place accurate dollar flgures on loss in social welfare from air travel inefficiencies. First, delays reported by airlines are based on schedules that take expected congestion into account. ${ }^{38} \mathrm{As}$ a consequence, one would expect reported delays to understate true congestion costs..$^{39}$ Second, it is problematic to assign monetary values to each individual passenger's lost work or leisure time. ${ }^{40}$ Nevertheless, even if it is not possible to show the precise level of inefficiency in the system, the statistics above indicate the magnitude of the problem.

\section{II \\ AIRPORT ECONOMICS \\ A. Supply of Airport Resources}

\section{Scarcity}

Airport service has attributes of a private good. One characteristic of a private good is that one person's enjoyment of the good excludes another's use. ${ }^{41}$ For example, once one person has consumed an apple, no one else may consume that same apple. Similarly, two planes cannot take off from or land on the same runway at the same time. ${ }^{42}$ Though the runway is not depleted like the apple, use of a given runway at a given time is limited to a choice among competing aircraft operators. Since only one aircraft may use a given airport resource at a time, there is an opportunity cost imposed by an aircraft's use of the airport. That is, one plane's use of the runway carries with it the opportunity cost, or the value of the alternative use, of

34. Remarks by the President, supra note 3, at 1.

35. Flights Will be Late More Often if FAA Doesn't Act, Airlines Warn, supra note 2.

36. Id. (noting delay costs of $\$ 4.5$ billion).

37. Flights Will be Late More Often if FAA Doesn't Act, Airlines Warn, supra note 2.

38. ECKERT, supra note 17, at 15-18 (noting that flights which are up to fifteen minutes late are considered on time).

39. Id.

40. Id. at 18 .

41. Robert CoOter \& Thomas Ulen, LAw \& Economics 106 (2000).

42. ECKERT, supra note 17 , at 13 . 
that runway space. ${ }^{43}$ Given limited availability of airport resources, there must be some method of allocating the existing resources among possible prospective aircraft operators, ${ }^{44}$ because building more, larger, or better airports imposes costs on society.

In the United States, prices set by the free market function as the primary sorting mechanism. ${ }^{45}$ Prices serve at least two purposes: they distribute goods to those who value them most, and, over time, they signal the efficient quantity of investment necessary to maintain or achieve satisfaction of customer desires. ${ }^{46}$ But, when it comes to allocating airport resources among competing aircraft operators, airports do not operate like profit-maximizing firms. ${ }^{47}$ Instead, most domestic airports make access to airports available on a first come, first served basis. ${ }^{48}$ Those aircraft willing to wait in line get the use of the airport. ${ }^{49}$ Furthermore, airports generally allocate their costs to aircraft operators in takeoff and landing fees based on aircraft weight. These fees represent only the costs of running the airport which cannot be recovered from landside airport revenues. ${ }^{50}$ Though weight-based cost recovery coupled with the queuing system may yield uncongested airports when resources are not scarce, given the scarcity at many airports, this pricing system can result in serious congestion problems. ${ }^{51}$

\section{Runway Capacity}

A full understanding of the factors which determine airport capacity requires an understanding of the relationship between airport capacity and the cost of providing airport services. The operational capacity of an airport is determined by its runway and taxi systems together with its access and control systems. ${ }^{52}$ The cost of the runway and taxi systems is, in turn, determined by the nature of the aircraft anticipated to use the airport. ${ }^{53}$

Aircraft can differ in many ways, but from an airport's perspective, one important way to distinguish among aircraft is their "footprint

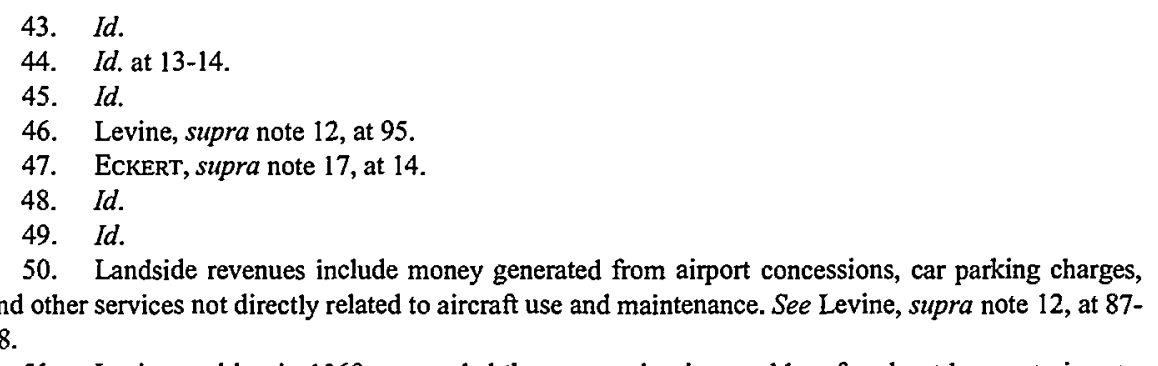

51. Levine, writing in 1969 , contended that congestion is a problem faced not by most airports, but only by relatively few airports in large metropolitan areas. Id. at 81 . In the last 32 years, however, the problem of congestion has spread to many more airports. E.g., Doganis et al., supra note 26, at 19294.

52. Levine, supra note 12 , at $82-83$.

53. Id. at 83 . 
pressure," the pressure an aircraft exerts on a runway or taxiway during takeoff or landing. ${ }^{54}$ This pressure is determined by a combimation of the aircraft's weight, the number and spacing of wheels in its landing gear, and the contact area of its tires. ${ }^{55}$ Pressure on a runway is lower for aircraft of lighter weight and with more wheels, wider spaced wheels, or larger surface area of tires hitting the ground. Aircraft designers have an incentive to design landing gear that are as small and light as possible, given an aircraft's projected weight, in order to save weight and space that can be used for profitable payload. ${ }^{56}$ Small landing gear usually have fewer wheels which are inore closely spaced and more narrow. As a consequence, an unconstrained designer will maximize the aircraft's footprint pressure. ${ }^{57}$ But, an aircraft engineer's design decisions have real world effects on an airport's cost structure. The higher the footprint pressure of anticipated aircraft, the stronger the runway must be. The stronger a runway must be, the higher its cost per foot. ${ }^{58}$ Thus, the imstincts of an aircraft design engineer will impose costs on the airport that may not correspond to strict weightbased takeoff and landing fees. ${ }^{59}$

Another factor in an airport's costs is the size of its runways. A runway's size depends on the size, performance, and type of aircraft anticipated to land there. ${ }^{60}$ Expected aircraft size will determine how wide the runway and taxiway should be as well as the radius of taxiway curves. The performance of aircraft will determine how long the runways must be. Aircraft that make long-haul voyages, requiring large amounts of fuel and holding many passengers, typically weigh more than short-range aircraft. ${ }^{61}$ The lower the aircraft's thrust-to-weight ratio, the slower the acceleration and the longer the runway needed for takeoff. ${ }^{62}$ Thus, weight is a useful proxy for some of the costs that aircraft impose on airports, such as wear on runways. However, for other costs, such as using scarce landing slots, weight may be a less helpful proxy or even run counter to a fair and efficient system. Worse, weight-based fees give incentives opposite to those of more demand-based systems since they yield higher charges for aircraft holding more people or freight which may value the services more than smaller aircraft with fewer people.

54. Id. at 83-84.

55. Id. (citing R. HoRonjeff, Planning and Design of Airports, 337-39, 358-62, 382-85 (1962)).

56. Id. at $83-84$.

57. Id.

58. Id. at 83 .

59. Id. at 84 .

60. Id.

61. Id.

62. Id. 


\section{B. Demand for Airport Services}

Were airport use uniform throughout all hours of the day and all days of the week, airport congestion at large airports would strongly diminish. ${ }^{63}$ However, under the current system, the preferences of airlines and general aviation, not forced to account for the costs they impose on other airport users, guide the scheduling of both departures and arrivals. As a consequence, airport use peaks during mornings and the afternoon and early evening hours, ${ }^{64}$ and overall is higher on Fridays than on any other day of the week. ${ }^{65}$ Air traffic is much heavier around the holidays and during the summer, peaking in August. ${ }^{66}$ Unfortunately, airports do not usually vary landing fees according to the time of day, week, or year. Put another way, because airports do not charge lower fees during less traveled times and higher fees during busier times, takeoffs and landings tend to bunch around popular hours of the day and preferred days of the week and year. ${ }^{67}$ These popular times, or peak-time periods, can be defined as any time period when demand for airport resources outstrips an airport's ability to supply them at the given price. The consequence of attempting to crowd in more takeoffs and landings than can fit within a given time period is that some users of the airport will face delays.

An aviator's preferences for takeoff and landing slots are not uniform across airports that offer the services necessary for his aircraft. ${ }^{6}$ For instance, when a small, general aviation aircraft ${ }^{69}$ is deciding between landing at Logan International Airport in Boston or at a smaller nearby airport, such as Hanscoin Airfield, built only to accommodate general aviation traffic, larger Logan may appear more attractive for several reasons. Logan may be situated more conveniently than the general aviation airport for travel into and out of Boston. In addition, Logan may offer better opportunities to connect with commercial flights beyond the range of the aviator's plane. Finally, Logan may provide better servicing or landing facilities. Thus, faced with a choice between taking off and landing at Logan or at a smaller, less-busy, general-aviation-only airport, the aircraft operator will choose not according to price differentials, which will likely be comparably small, but rather based on the airport which maximizes his preferences for convenience and services. Consequently, the aviator's decision will

63. See Eckert, supra note 17 , at 14; Robert M. Hardaway, The Management and Growth of Airport Regulation, Law, ANd Public Policy 201 (1991).

64. ECKERT, supra note 17, at 14-17.

65. Id.

66. Id. at 14 .

67. Id. at 14-15.

68. See Levine, supra note 12, at 92-93; see also Doganis et al., supra note 26, at 203 (finding that most British passengers choose the airport nearest to their destination that has the services they require).

69. A general aviation aircraft is a privately-operated aircraft. For the purposes of this example, I will assume that the aviator is the only occupant of the aircraft. 
severely underestimate the costs that he will impose on other airport users. ${ }^{70}$ This pattern is true even if the general aviation airport has no one else landing while Logan is piled high with waiting aircraft.

Though airport fees generally do not vary with the level of congestion, some airport users do choose to alter their travel arrangements because of airport delays. ${ }^{71}$ Passengers who place a high value on the time lost during airport congestion may shift their flights to less traveled hours given the same ticket price. ${ }^{72}$ Airlines also voluntarily shift some of their flights to off-peak times or to less congested airports to accommodate capacity constraints. ${ }^{73}$ Still, many airport users fail to internalize fully the costs they inpose on other airport consumers when they choose to use one airport over another or fly in one time slot over another.

\section{Slot Pricing and Airport Funding}

Slot pricing is slightly more complicated than the simple weight-based fees mentioned earlier. Slots at most airports are priced according to a method called residual cost recovery that uses weight to apportion costs at the end of the process. Cost recovery means an airport inay recover from its aircraft operators only those costs it mcurs running the airport. ${ }^{74}$ Residual cost recovery usually requires an airport to divide itself into two cost and revenue centers: aeronautical and nonaeronautical. ${ }^{75}$ An airport applies any earnings ${ }^{76}$ from the non-aeronautical center toward costs incurred by aeronautical users. Thus, to the extent the concessions, taxi services, and other nonaeronautical parts of an airport generate earnings, the excess inoney must be applied to lower fees for aeronautical users. ${ }^{77}$ For example, since 1959, Wayne County Airport in Detroit has operated under a financing agreement with airlines that land there. ${ }^{78}$ Under this basic agreement, the airport does not maximize its profits, as a typical business would, but rather sets airline fees to make up for any shortfalls in expenses. The imcoine formula is:

(EXPENSES) - (LANDSIDE REVENUE) $=$ AIRLINE FEES. ${ }^{79}$

Or, putting numbers into a table format:

70. See Levine, supra note 12, at 93.

71. ECKERT, supra note 17 , at 15 .

72. Id.

73. Id.

74. See Levine, supra note 12 , at 87.

75. See id. at 87-88.

76. Earnings are defined as revenues generated in excess of costs.

77. See Levine, supra note 12 , at 87.

78. See John M. Kost, Detroit Metropolitan Airport: A Case for Privatization, 8 MACKINAC CENTER REPORT, Oct. 27, 1988. The airport and airlines signed a fifty-year agreement set to expire in 2009.

79. Id. at 11 . 
Airline Parties' Flight Fees at Detroit Metropolitan Airport for $1985^{80}$

\begin{tabular}{|l|l|}
\hline Total Airport Expenses & $\$ 45,875,000^{81}$ \\
\hline Total Landside Revenue (excludes flight fees) & $\$ 41,737,000$ \\
\hline Total Flight Fees Revenue & $\$ 4,138,000$ \\
\hline Total Landing Weight, Airline Parties (in thousands of pounds) & $\$ 9,490,825$ \\
\hline Flight Fee per Thousand Pounds of Landed Weight & $\$ 0.436^{82}$ \\
\hline
\end{tabular}

The airport's first step is to subtract its landside revenues from its expenses. It then sets airside revenues to provide for the remaining expenses. Finally, it apportions the remaining expenses by aircraft weight. Thus, the system treats its airside revenue stream as a fund of last resort, only to be tapped if landside revenues are insufficient to meet all the costs of running the airport and only recoverable to the extent needed to cover remaining airside costs. ${ }^{83}$ Put another way, aircraft operators are only charged the residual costs after landside fees are applied to airside costs.

Since aircraft fees depend on both airside and landside costs and revenues, it is useful to understand the funding and pricing systems for all parts of the airport. Moreover, doing so will provide a useful baseline from which to judge financing and pricing for takeoff and landing slots. The traffic control tower and instrument approach facilities control access to the traffic control system. ${ }^{84}$ For most airports, the tower facilities consist of an observation point connected by phone to the FAA's Air Route Traffic Control Center. There is typically an instrument landing facility for use on approach to the airport. ${ }^{85}$ While the cost of installing and operating this system varies with the size of the system, the FAA finances all the costs of installing and operating the control tower and instrument landing facilities. ${ }^{86}$ Tax revenues cover operation and installation, some of which come from excise taxes imposed on passenger ticket sales and on certain aircraft fuel. ${ }^{87}$ Though airports may purchase and install this equipment on their own, they have good reason not to, given the federal subsidies available and the high technical standards set by the FAA. Instead, airports find it more profitable to pay lobbyists to encourage the FAA to install new facilities when old ones become obsolete. ${ }^{88}$

80. See id. To reach the total airport revenue and total landing weight, it was assumed that total expenses equal total revenues and that the flight fee was $\$ 0.436$ per thousand pounds of landed weight.

81. See id. at 10. It was assumed that expenses equal the figure for gross airport revenues, since under the basic agreement revenues must equal expenses.

82. See id. This number may not be completely accurate given that it is for the year 1986 rather than 1985. As a consequence, the total landing weight may also be inaccurate. Regardless, this example illustrates the process the airport uses to generate flight fees.

83. See Levine, supra note 12 , at $87-88$.

84. See id. at 82 .

85. See id.

86. Id. at 83 .

87. Id.

88. Id. at $82-84$. 
The landside facilities, including passenger and freight-handling facilities and connections to ground transportation, are generally very lucrative. ${ }^{89}$ The terminals typically operate on a monopoly basis, with revenues used to subsidize the landing and taxiway areas. ${ }^{90}$ Airport parking, taxi services, restaurants, and gift shops operate as concessions typically given to the highest bidder. ${ }^{91}$ The concessions operators pay fees to the airport for the use of the facility. ${ }^{92}$ As noted above, terminal facility revenues, like concession fees, go to the airport operator who applies those revenues against rates charged to aircraft. As a consequence, funds from takeoff and landing slots are the last place an airport operator turns, and does so only to the extent that airport costs have not already been recovered through other parts of airport operations. ${ }^{93}$

III

\section{Economic Models Underlying Airport Charges}

During the first hearings on the Federal Airport Act, ${ }^{94}$ a consensus formed around the notion that airports were public utilities that ought to be operated to earn a "reasonable return on a prudent investment.".95 While considerable controversy surrounded the amount of the subsidy airports deserved, there was little debate over how to price the use of takeoff and landing slots: cost-recovery pricing would be used. ${ }^{96}$ As explained earlier, cost recovery requires airports to charge aircraft operators only the fees necessary to recover the cost of maintaining the runway system. Each aircraft operator pays a proportional share of those maintenance costs based on the weight of its aircraft. ${ }^{97}$ Today, cost-recovery pricing remains the dominant method for pricing takeoff and landing resources. ${ }^{98}$ During these first hearings, no one proposed allocating airport capacity according to a demand-based pricing mechanism. In fact, it was not until the mid-1960s, when airport congestion began to take hold, that anyone seriously discussed the inatter.99

89. See id. at 85 .

90. ECKERT, supra note 17, at 20.

Id.

91. Levine, supra note 12 , at 86 . Concessionaires may also be selected by historical relationship.

92. Id. at 87 .

93. See id. at 89.

94. 49 U.S.C. $\$ 1109$ (1964).

95. See Levine, supra note 12, at 86 (citing Federal Airport Act: Hearing on S. 2 and S. 34 Before the Senate Interstate and Foreign Commerce Comm., 79th Cong. passim (1945); Federal Airport Act: Hearing on H.R. 3 I70 Before the House Interstate and Foreign Commerce Comm., 79th Cong. passim (1945)).

96. Id. at 87.

97. See Steven A. Morrison, The Equity and Efficiency of Runway Pricing, 34 J. Pur. Econ. 45, 47 (1987).

98. See id.

99. See Levine, supra note 12 , at 87. 
For an analyst interested in efficient resource allocation, an important effect of prices is their ability to signal current and future desired investinent. Yet, those who support the cost-recovery methodology often neglect these signaling aspects of prices while they concentrate on the function of prices to generate revenue. ${ }^{100}$ Their fears are twofold. First, they are concerned that, left unchecked, the revenues generated from aircraft operators, and by extension, their passengers, will be excessively high. They worry that an airport may exploit its position as a natural monopoly and raise takeoff and landing fees to an exorbitant level. ${ }^{101}$ Second, such analysts believe that even if fees are not set too high, the fees that are generated may be diverted impermissibly to non-airport use. ${ }^{102}$ Motivated largely by these worries, cost-recovery proponents focus on paying for a known level of airport capacity and ignore efficient distribution of current capacity. They advocate matching airport capacity to need while they determine need without reference to price. ${ }^{103}$

Those who advocate cost-recovery pricing for airside services simultaneously advocate profit maximization in the landside portions of the airport. ${ }^{104}$ According to two prominent experts on airport financing, airports should apply revenues from ancillary services (including concessions, terminal, and storage) toward subsidizing the operation of the runways and taxiways, so that aircraft are not left to pay all the costs of providing aeronautical services:

Now while it is not ordinarily regarded to be a legitimate objective of the airport owner to derive a "profit" on the over-all operation of the airport, common prudence dictates that efforts be made to put the facilities to productive uses whenever possible; otherwise there will be a simple, unconscionable waste of land and other economic resources. At the same time, when facilities are leased ... the airport owner should derive full economic rental from the facilities rather than simply recover "costs." Otherwise, the concessionaire or other lessee may himself gain the monopoly profit of the site which in simple equity ought to redound to the owner....

It is believed that the "profit" may appropriately be offset against other costs of common facilities (runways, taxiways, etc.) which are directly assignable to airport users. It is now realized that this treatment may result in low direct charges against the aviation users of the airport. On the other hand, these "profits" have in large

100. Cf. id.

101. See Stephen E. Creager, Note, Airline Deregulation and Airport Regulation, 93 YALE L.J. 319,322 (1983).

102. See S. Rep. No. 93-12 (1973), reprinted in 1973 U.S.S.C.A.N. 1434, 1446.

103. Levine, supra note 12 , at 87.

104. Id. at $87-88$. 
measure been derived from patrons of the airports, and thus might be considered to be an indirect form of user contribution. ${ }^{105}$

Zettel and Horonjeff believe that airports ought not to try to make a profit from aircraft. Instead, they believe that airports should try to make as large a profit as possible im ancillary landside services; otherwise, there will be improper redistribution of monopoly profits toward ancillary service operators. ${ }^{106}$

One explanation for this difference in treatment between landing fees and ancillary fees is that cost-recovery proponents seek to boost the economy by subsidizing and thus encouraging air travel. A second possible rationale is that cost-recovery proponents hope to make the cost of air travel affordable to more people than if aircraft passengers paid the full cost their use of aircraft imposed on the airport. Indeed, in the preceding quotation, Zettel and Horonjeff note the equity of a system that takes money from landside services and uses it to subsidize fiight costs. Furthermore, Zettel and Horonjeff's explicit goal was not to maximize the aggregate value placed on the takeoff and landing slots at an airport, but rather to ensure sufficient use of the airport to avoid "unconscionable waste." With such a goal in mind, it is no wonder that their pricing prescriptions do little to rank higher value airport users over lower value ones. But in the modern air travel system with its large congestion costs (much larger than fifty years ago), cost-recovery pricing may do more harm than good for the economy. Additionally, one could quarrel with the claim that it is preferable for ancillary landside profits to be applied toward the costs of airport users because those users indirectly contribute toward such profits.

Though applying ancillary profits toward takeoff and landing fees may be fair to the extent it uses money spent in the airport by airport users to subsidize airside fees, the costs of such a system may be undesirable because it creates a smaller total pie for everyone involved. Specifically, subsidizing airside services may cause airport resources to be priced below the market equilibrium. With prices below the supply and demand equilibrium, deinand outstrips supply and a shortage arises in the quantity of airside services on offer. As a consequence, soine aircraft passengers who would be willing to pay more for less congested airport use than the belowcost, weight-based fees, cannot do so. By artificially depressing rates charged to airport users below marginal cost, the current system yields an inefficient allocation of scarce takeoff and landing resources. The resulting misallocation of resources leaves some users who would be willing to pay

105. Id. (citing R. Zettel \& R. Horonjeff, Practice and Theory of Airport Financing (Univ. of Cal., Berkeley, Inst. of Transp. \& Traffic Eng'g Research Report No. 24, 1956)).

106. Levine, supra note 12 , at 88. 
more and wait less with no alternative but to wait their turn im line or fly at another time. ${ }^{107}$

One may also object to an airport's recovery of monopoly profits in the landside realm. Prices set at monopoly level are inefficiently high whether they are imposed on users from the air or on the ground. ${ }^{108}$ Also, monopoly control leads to suboptimal supply of airport resources. ${ }^{109}$ It is unclear why the framers of federal airport legislation did not find this point more worrisome. Matters only become worse when airports must pay some portion of these excess landside profits to reduce air fees to below-cost levels. ${ }^{110}$ Given the perverse economic incentives of having the monopoly rents generated in one part of an airport in order to subsidize the belowcost rents in another, one is left to conclude that two economic wrongs do not "right" but rather aggravate the congestion of our airports.

In advocating a more flexible pricing systein, this Comment does not mean to imply that airports should be free from all regulation of takeoff and landing slot pricing. There is a concern that airports may be natural monopolies which can abuse their market positions. ${ }^{111}$ Airports could use their market power to set takeoff and landing fees far above what a free market would bear, thereby choking off interstate commerce. ${ }^{112}$ Nonetheless, there are several reasons why it is unlikely that airports would charge inonopoly prices even if they were monopolies. First, the statute requires airports to set fees at a "reasonable" level. ${ }^{113}$ Second, many airports, especially those in large urban centers, operate in highly competitive environments. Were one airport to charge excessive rates, other nearby airports would have a strong incentive to undercut those prices. As a consequence, some airlines or independent pilots would abandon the pricier airport for cheaper alternatives. Finally, given that airports are typically owned by quasi-public entities whose decisions are made or influenced by local political institutions, it seems highly unlikely that airports would charge monopoly prices for fear of costly political backlash. Thus, even if airports used more flexible pricing, it is unlikely that they would set prices at

107. The problem here is really twofold. First, prices are set so low that there is excess demand for the peak-time slots. Second, there is a problem in charging a flat fee, that is, a fee that does not vary with the level of demand or congestion. Though congestion could be reduced by merely raising the flat fee (for example, by raising the weight-based prices), a full solution would require an airport to charge a rate that varied according to the costs imposed as well.

108. Though the framers of federal legislation on airports may have thought that someone had to earn a monopoly profit from landside services, it is not difficult to imagine a system in which nonaeronautical prices are restricted below monopoly levels. Such a system would not only have the benefit of rescuing consumers at airports from excessively high prices, but it would also provide a less distorted signal about the best places for future investment in landside goods and services.

109. See Levine, supra note 12 , at 88 .

110. See id. at $88-89$.

111. See infra Part V1.D.

112. See Creager, supra note 101 , at 322.

113. 49 U.S.C. $\$ 1513$ (b) (1999). 
monopoly levels. And preventing airports from varying their prices may ultimately achieve what cost-recovery advocates hoped to avoid: unconscionable waste of airport services.

\section{IV \\ FEDERAL Statutes}

Rather than legislate directly its view of the appropriate rate structure for airports, Congress has set out several broad statutory requirements for airport fee structures and let the Secretary of Transportation specify fee methodology and adjudicate fee disputes. The statutes on airport pricing give little guidance concerning the methodology airports may use when setting rates for the use of airport resources. On the one hand, Congress has permitted all airports to collect "reasonable rental charges, landing fees, and other service charges from aircraft operators for using airport facilities." $" 114$ On the other hand, federal law requires airports that receive federal grants to "be available for public use on reasonable conditions and without unjust discrimination." ${ }^{115}$ Federal statutes also insist that airports be "as self-sustaining as possible under the circumstances ... including volume of traffic and economy of collection." $" 116$ Furthermore, Congress has limited the Secretary's imvolvement in rate disputes: he "may only determine whether the fee is reasonable or unreasonable and shall not set the level of the fee." $" 17$

\section{A. User Fees}

Though Congress has not set out explicitly what sort of fee constitutes a "reasonable" one, the legislative history provides some idea of Congress's intent in this area. In 1973, Congress enacted the Anti-Head Tax Act ${ }^{118}$ in order to reverse the Supreme Court's decision $\mathrm{m}$ EvansvilleVanderburgh Airport Authority District v. Delta Airlines. ${ }^{119}$ Evansville upheld passenger head taxes for aviation purposes. The Court found valid both Evansville, Indiana's "'use and service charge of One Dollar" for each enplaning comnnercial passenger and New Hampshire's levy of a one dollar enplaning charge for passengers on large commercial airlines, with a fifty cent charge on each passenger boarding sinaller airplanes. ${ }^{120}$ In Evansville, the money was earmarked for upkeep and improvement of

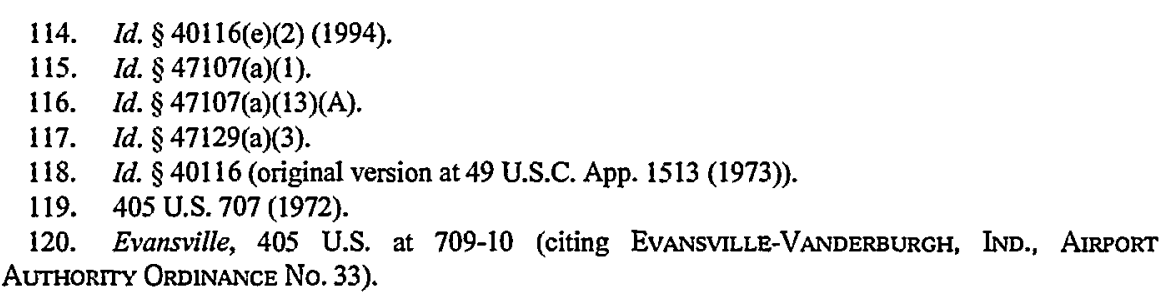


airport resources, while New Hampshire used half the revenue for its state aeronautical fund with the other half going toward the airport authority. ${ }^{121}$

The Supreine Court upheld the passenger enplanement charges because they did not impermissibly burden a citizen's constitutional right of travel. ${ }^{122}$ The Court rejected the airlines' analogy of the airport head tax to an unlawful Nevada scheme that levied a one dollar tax on anyone leaving the state of Nevada, regardless of the form of transportation used.123 Distinguishing the airport's charge from Nevada's charge, the Court implied that because Nevada's charge was not based on the cost of providing a discrete state service, there was nothing to prevent Nevada from making the charge arbitrarily high, thereby burdening imterstate travel. ${ }^{124}$ The Court found that the airports were simply collecting a reasonable amount of head tax from passengers to defray the cost of maintaining very expensive, stateprovided facilities. ${ }^{125}$ It also concluded that such charges did not discriminate against interstate commerce or travel because the states levied the same tax on intra and interstate uses. According to the Court, the charges were a fair estimate of the benefit passengers derived from use of the airport facilities and were not excessive in relation to the costs incurred by the airports. ${ }^{126}$ The Court found the head tax to be permissible in the absence of contrary congressional action. Indeed, the Court found affirmative support in the Airport and Airway Development Act of 1970 for maintenance of a fee structure which would make an airport as self-sustaining as possible. ${ }^{127}$

In reversing Evansville, Congress indicated several overlapping grounds for rejecting the head tax. First, Congress worried that any tax on air travel would "inhibit the flow of interstate commerce and the growth and development of air transportation." 128 Evidence for this view comes from the Senate Commerce Committee Report's recounting of Philadelphia's experience with the head tax: "The head tax ... cuts against the grain of the traditional American right to travel among the States unburdened by travel taxes."129 Furthermore, the committee worried that a tax on airport use would induce some potential air travelers to use alternative means of transportation, inhibiting the growth and utility of air travel. ${ }^{130}$ Second, Congress opposed a non-uniform system of taxation

121. See S. Rep. No. 93-12, at 17 (1973), reprinted in 1973 U.S.C.C.A.N. 1434, 1446.

122. Evansville, 405 U.S. at 714.

123. Id. at 711-12. The Court relied on cases such as Freeman v. Hewitt, 329 U.S. 249, 253 (1946), for the proposition that a state may levy taxes on interstate commerce to make the commerce bear a fair share of the local government service it enjoys.

124. Id. at 712 .

125. Id. at 717 .

126. Id. at 717-20.

127. Id. at 721 .

128. See S. Rep. No. 93-12, at 4 (1973), reprinted in 1973 U.S.C.C.A.N. 1434, 1435.

129. Id. at 17 , reprinted in 1973 U.S.C.C.A.N. at 1446.

130. Id. at 22 , reprinted in 1973 U.S.C.C.A.N. at 1451. 
because it could lead to distorted incentives to use one state's airport rather than another's merely because of head tax differences. ${ }^{131}$ Third, Congress disagreed with the distributional consequences of a flat head tax among airport users. "The head tax imposes a flat rate on passengers, regardless of the distance traveled by the passenger. Therefore, the 'short-haul' passenger, paying a $\$ 1$ tax has the price of his ticket increased about $10 \%$ while a transcontinental passenger's ticket increases less than 1\%."132 Finally, Congress opposed head taxes because it wanted to prevent airports from diverting tax revenues away from aeronautical services. On this note, the Senate Report highlights the "most blatant example" of Philadelphia's head tax funds going into its general fund, unearmarked for air services. ${ }^{133}$ In sum, Congress sought to prevent states from imposing fees which would (1) inhibit the flow of commerce; (2) stifle air travel; (3) distort incentives to fly between similar airports; (4) impose inequities between short-and long-haul passengers; and (5) provide a temptation for airport owners to divert taxes away from airports.

\section{$\mathrm{V}$}

\section{Current Federal Regulation and Proposals for New Regulation}

Given the main thrust behind the Anti-Head Tax Act ${ }^{134}$ is to promote air travel in a fair and undistorted manner, it would make sense for the Department of Transportation ("DOT") to encourage pricing policies that result in the fairest and most efficient use of airports. Only by doing so can DOT prevent commercial airline flow from suffering and air transportation growth froin being hindered, especially in times of congestion. This Comment highlights two areas where DOT policy falls short of achieving Congress's goals. Speciflcally, the Comment concentrates on historic cost valuation of airport resources and peak-hour pricing. In each area, this Comment will set out DOT policy, explain problems with DOT prescriptions, and propose a new policy. The Comment argues for new regulatory policy that encourages airports to factor into slot prices more of the costs aircraft impose on other airport users. DOT should encourage airports to charge more to recover the opportunity costs of their land and their congestion costs during peak-hour operations. These policy changes would yield more efficient use of congested airport resources and require less federal funding for future airport expansion. But while airports should be permitted greater flexibility in the fees they charge, they should not be allowed to abuse any natural monopoly power they have over airport users. Accordingly, airport slot fees should be capped during off-peak times.

131. Id. at 4, reprinted in 1973 U.S.C.C.A.N. at 1435.

132. Id. at 22, reprinted in 1973 U.S.C.C.A.N. at 1451.

133. Id. at 17, reprinted in 1973 U.S.C.C.A.N. at 1446.

134. 49 U.S.C. $\$ 40116$ (1994) (original version at 49 U.S.C. App. 1513 (1973)). 
In DOT's most recent policy statement on slot pricing, "Policy Regarding Airport Rates and Charges,"135 DOT advocates two principles that would discourage airports from pricing slots in a more efficient manner. First, it insists that airports use historic cost to value their resources, and second, it leaves uncertain how a lawful peak-time pricing policy would work. As to the first principle, the Court of Appeals for the District of Columbia has vacated those portions of the policy which interpreted the Anti-Head Tax Act to require historic cost valuation of aeronautical resources and has remanded those matters back to the Secretary of Transportation. ${ }^{136}$ But because DOT is still deciding on replacement policies or better justification for its vacated positions, this Comment will discuss both issues.

\section{A. Federal Policy Should Permit Alternatives to Historic Cost Valuation}

DOT policy limits airports to charging airport users only the cost of providing aeronautical services and facilities. In determining the cost of providing facilities, DOT has required airports to value airfield resources at their historic cost, that is, their original cost to an airport when it bought the asset. ${ }^{137}$ This historic cost valuation ("HCV") requirement covers valuation of the land underlying the runways, taxiways, aprons, ramps, and roadway land. ${ }^{138}$ In defense of HCV, DOT contends that it is consistent with current practice, allows airports to recover their actual costs, and is easily administered and uncontroversial because it is based on accounting records. ${ }^{139}$ In the past, DOT has argued that historic cost is "the inost widely accepted methodology ... for both public finance accounting and ratemaking"140 and is the standard for establishing rates in regulated industries. Finally, DOT has asserted that HCV is necessary to avoid collection of revenues that are unlawfully above original costs of providing services. ${ }^{141}$

The DOT's justification for HCV is unpersuasive, however, and its insistence on HCV will prevent airports from more efficient resource allocation. Turning to DOT's first rationale, it is not clear that HCV is consistent with current practice. Indeed, only five years ago, when DOT first considered requiring $\mathrm{HCV}$, one airport representative pointed out that $\mathrm{HCV}$ would require a majority of airports to change the way they calculate fees

135. 61 Fed. Reg. 31,994 (June 21, 1996).

136. Air Transp. Ass'n of Am. v. Dep't of Transp., 119 F.3d 38, 45 (D.C. Cir. 1997).

137. 61 Fed. Reg. 32,020 (1996).

138. Air Transp. Ass' $n$ of Am., 119 F.3d at 40.

139. Id.

140. Policy Regarding Airport Rates and Charges, 60 Fed. Reg. 6906, 6911 (Feb. 3, 1995).

141. See id. 
for airport users. ${ }^{142}$ To be sure, HCV permits airports to recover their outof-pocket costs of buying the land beneath the airports. But it is not clear from a public policy standpoint that airports ought only to be entitled to recover their out-of-pocket costs on airport resources. We may believe that given the amount of risk involved in acquiring land for an airport, an airport owner should be able to receive a higher rate of return than mere historic cost recovery. ${ }^{143}$ Or, we may realize that restricting airport land to historic cost sends distorted signals about the appropriate level of future investment needed in airport resources.

Second, historic cost is not as easily administered as DOT contends. For those airports that have not kept purchase and expenditure records from their inception, it may not be easy to recreate that information retroactively. ${ }^{144}$ Indeed, many airports do not maintain detailed records of expenditures made decades ago when the airports were built. ${ }^{145}$ Until several years ago, when DOT began to require airports to keep such records, airports were under no requirement to keep such information. ${ }^{146}$ At airports that do not have such records, it would be easier to establish market rates or some similar measure of asset value than it would be to require reconstruction of historic cost figures. ${ }^{147}$ Indeed, in the absence of such records, there can be disputes over the value of airfield resources. ${ }^{148}$

At the same time, market valuation of airport resources might not be as difficult as DOT assumes. Rejecting in part the analogy between traditionally regulated industries and airports, one notices that airfield assets are much more tangible and prone to market evaluation than are the assets of many utilities. As a result, valuation of airfield resources (such as land) may be more straightforward than valuation of utility plants and equipment. As one court observed, the former is easier to value than the latter because "there is no need to reconstruct a hypothetical asset in order to account for technological changes, and there is often (indeed, perhaps usually) a ready market in parcels sufficiently comparable for a professional appraiser to extrapolate with some confidence."149 Given a

142. See Patricia A. Hahn, General Counsel, Airports Council International-North America, Comments on DOT/FAA Policy Statement Regarding Airport Rates and Charges, Docket 27782, May 4, 1995.

143. It is true, however, that airport owners are permitted to eam "'a reasonable retum on a prudent investment."' Levine, supra note 12, at 86 (citation omitted in original).

144. Hahn, supra note 142 , at 7 .

145. Id. at 7-8.

146. Id.

147. Id.

148. See Air Transp. Ass'n of Am. v. Dep't of Transp., 119 F.3d 38, 44 (D.C. Cir. 1997) (observing that the airlines valued the historic cost of LAX land higher than the airport did).

149. Id. (quoting City of L.A. Dep't of Airports v. United States Dep't of Transp., 103 F.3d 1027, 1033 (D.C. Cir. 1997)). 
market in real estate, airports can get fairly reliable estimates of the fair market value of many of their resources.

Another reason to reject DOT's historic cost requirement is that its analogy to traditionally regulated industries is flawed. The original Federal Aviation Administration Authorization Act ${ }^{150}$ ("FAAAA") did not intend for DOT to import all aspects of public utility regulation into the area of airport regulation. ${ }^{151}$ Indeed, there is an important difference between the two. For industries regulated as public utilities, the agency overseeing the utility generally has the authority to set the rate to be charged to users. In contrast, Congress expressly forbade DOT to set fee amounts for airport takeoff and landing slots. ${ }^{152}$ Given that Congress did not intend DOT to take on a price-setting role, it is plausible that Congress also wanted to permit airports greater freedom in choosing valuation methods. But to the extent that DOT can determine the exclusive valuation method to be used, a portion of what an airport can charge will in effect be fixed by DOT. It is not clear whether Congress intended to allow DOT such interference with airport pricing autonomy. ${ }^{153}$

Finally, DOT's assertion that $\mathrm{HCV}$ avoids unlawfully high prices merely begs the question. The issue is whether HCV is mandated by the Anti-Head Tax Act. To say that HCV is legally compelled is merely to restate DOT's conclusion without providing any independent support for the proposition. The net effect of $\mathrm{HCV}$ of airfield resources is to provide a subsidy to carriers in the form of takeoff and landing fees that reflect neither demand for nor cost of the facilities provided. DOT does not make a persuasive case either for a reading of the Anti-Head Tax Act that requires $\mathrm{HCV}$, or for HCV as a matter of public policy.

\section{Opportunity-Cost Valuation}

The Supreme Court has never held that historic cost represents the only true measure of cost. ${ }^{154}$ Nor has DOT cited any case or regulatory decision that supports its view. On the contrary, agencies that regulate utilities consider "opportunity cost" when setting rates to cover the actual costs

150. 49 U.S.C. $\$ 40101$ (1994) (original version at 49 U.S.C. $\$ 14501$ (1958)).

151. Recall, for instance, that the Secretary of DOT does not have rate setting power, whereas other regulatory commissions do have such power. See supra note 115 and accompanying text.

152. 49 U.S.C. $\$ 47129$ (a)(3) (1994).

153. Though Congress has not expressed a view beyond denying DOT the power to set the level of rates, the Court of Appeals for the District of Columbia has found that DOT has not offered adequate justification for permitting airports to only value resources at their historic cost. Air Transp. Ass' $n$ of Am., 119 F.3d at 44.

154. See City of L.A. Dep't of Airports v. United States Dep't of Transp., 103 F.3d 1027, 1032 (D.C. Cir. 1997) (noting that the Supreme Court has never held that historic cost represents the only true measure of cost). 
mcurred to provide a particular service. ${ }^{155}$ Indeed, past Supreme Court decisions protect a regulatory entity's ability to impose valuation methods other than historic cost. In Smyth v. Ames, for instance, the Court held "that the basis of all calculations as to the reasonableness of rates ... must be the fair value of the property being used... for the convenience of the public."156 Though the Court later questioned Smyth, ${ }^{157}$ it did not abandon its view of the benefits of fair market valuation. Rather, it held that " $[t]$ he Constitution does not bind rate-making bodies to the service of any single formula or combination of formulas." 158 In Smyth, the Court permitted rate makers to use current market valuation. ${ }^{159}$ Since then, however, the Court has not concluded that opportunity-cost valuation was an impermissible valuation method. ${ }^{160}$

Furthermore, to achieve efficient public policy, DOT should allow airports to include in their rate base a charge for the fair market value of the land on which the airport is built. Doing so would signal both the resource's value to airport users and the appropriate level of future investment. Having seen the wisdom of such an approach several years ago, the City of Los Angeles nicluded in Los Angeles International Airport's (LAX) charges to aircraft operators an amount equivalent to the fair market value of the airport's land. ${ }^{161} \mathrm{~A}$ closer look at the LAX case highlights the benefits and objections to permitting opportunity-cost valuation of airport land.

\section{a. LAX Case}

In 1993, Los Angeles decided for the first time to include in aeronautical costs a charge for the current fair market rental value of the land on which LAX resides. The City argued that it should be entitled to recover its opportunity costs as measured by the value of the airport land, because only then would the airport be compensated fully for the opportunity cost of using the land as an airport rather than the next most profitable alternative. ${ }^{162}$ As a consequence, new landing fees jumped from $\$ .51$ per 1,000 pounds in 1992 to $\$ 1.56$ per 1,000 pounds in $1993 . .^{163}$ Faced with significantly higher charges, the airlines filed a complaint with DOT. In its first administrative response to the fee challenge, DOT concluded that the

155. Id. (citing Penn. Elec. Co. v. FERC, 11 F.3d 207 (D.C. Cir. 1993)). The City of L.A. Dep't of Airports court found that opportunity cost is germane to the Energy Policy Act's requirement that costs are recovered.

156. 169 U.S. 466,546 (1898).

157. Fed. Power Comm'n v. Natural Gas Pipeline Co., 315 U.S. 575, 602-03 (1942).

158. Id. at 586 .

159. See Smyth, 169 U.S. at 546-47.

160. Duquesne Light Co. v. Barasch, 488 U.S. 299, 309 (1989).

161. See City of L.A. v. United States Dep't of Transp., 165 F.3d 972 (D.C. Cir. 1999).

162. Id. at 974-75.

163. Id. 
reasonable landing fee requirement prohibited an airport from including in its rates the opportunity cost of the land on which the airport resides. ${ }^{164}$ It found that the Anti-Head Tax Act restricts airports to recover only the historic cost valuation of airfield land. ${ }^{165}$ On review of DOT's decision, the Court of Appeals for the District of Columbia Circuit rejected DOT's rationale. Finding no basis in the Anti-Head Tax Act for DOT's prohibition on the use of opportunity cost in land valuation, the court vacated DOT's decision and remanded it for "fuller consideration of the respective merits of the historic cost and (opportunity cost) methodologies." "166 The court also granted a remand to DOT for a similar 1995 fee proceeding. ${ }^{167}$

On remand, DOT consolidated the 1993 and 1995 proceedings and again found LAX's use of opportunity costs invalid. However, this time DOT attacked LAX's decision on different grounds than in its previous rate hearing. DOT noted that LAX was required as a recipient of federal grant money to keep the airport available for public use. ${ }^{168}$ It also pointed out that a grant recipient cannot make changes in an airport's layout unless the Secretary of DOT decides that the change will not "'adversely affect the safety, utility, or efficiency of the airport." 169 Reading the above two provisions together, DOT concluded that the City of Los Angeles was not entitled to use the airport land for any purpose other than as an airport. Because the City could not lawfully convert the land to another use, DOT reasoned that there was no real opportunity cost in using the land as an airport. As one judge paraphrased DOT's argument, "the City is like an owner of a hot dog stand who claims his opportunity cost is the revenue he would earn by selling cocaine rather than hot dogs." "170 Thus, the agency concluded that permitting recovery for an opportunity that did not lawfully exist would create an unreasonable charge on aeronautical users.

DOT's analysis went further. Even assuming that conversion of the airport land was lawful, DOT rejected the contention that there was any real opportunity lost by using the land as an airport. It reasoned that the costs of ceasing to operate LAX would far outweigh the benefits of the next most profitable use of the airport land. In comparing the opportunity costs, DOT treated the City rather than the airport as the appropriate

164. See Los Angeles International Airport Rates Proceeding, Order 95-6-36 (Dep't of Transp., Aviation and Int'l Affairs June 30, 1995) (final decision).

165. See City of L.A., 165 F.3d at 975.

166. Id. (quoting L.A. Dep't of Airports. v. United States Dep't of Transp., 103 F.3d 1027, 1032 (D.C. Cir. 1997)).

167. See id. at 975 .

168. See Los Angeles International Airport Rates Proceeding, supra note 164; Second Los Angeles International Airport Rates Proceeding (Dep't of Transp., Aviation and Int'l Affairs Dec. 23, 1997, available at 1997 DOT av. LEXIS 673).

169. City of L.A., 165 F.3d at 976 (quoting 49 U.S.C. $\S 47107(\mathrm{a})(16)(\mathrm{c})(1982)$ ).

170. Id. at 977 . 
economic unit. ${ }^{171}$ On the cost side of the ledger, it noted that the City would either have to build a new airport, expand an existing one, or go without an airport. DOT estimated the last option as yielding a state and local tax revenue loss of $\$ 1.7$ billion a year and a direct, indirect, and induced economic detriment of $\$ 37$ billion per year. ${ }^{172}$ Furthermore, Los Angeles would lose its current revenue stream from users of LAX. The City had claimed that projected revenues from the next best alternative use of the airport land would yield less than $\$ 15$ million per year. ${ }^{173}$ Thus, DOT concluded that the costs of not operating LAX (\$38.7 billion) far outweighed the benefits to the City of implementing its next most profitable alternative use ( $\$ 15$ million). ${ }^{174}$ DOT added that the cost-benefit analysis would be similar if the City either built a new airport or expanded an existing one. ${ }^{175}$ On appeal, the reviewing court found DOT's new position was not a clear error in judgment and upheld its findings. ${ }^{176}$

The position of DOT and the courts mirrors Zettel and Horonjeff's view: ${ }^{177}$ it concentrates on how much revenue will be generated using a pricing methodology while it ignores efficient allocation of resources. DOT's success is largely attributable to its ability to frame the case around whether Los Angeles had a more profitable opportunity and whether it could pursue that opportunity legally. To be sure, one can make a case that DOT's arguments on those scores are fiawed. But to do so would be to accept, to a certain extent, DOT's worldview and to miss the larger issue. Even if the City could not legally convert the airport to its next most valuable use, disallowing it to price its slots as if it could yields unfair and inefficient allocation of airport resources. Had the City successfully framed the issue as "we want to recover the fair market value of airport land because doing so will yield more efficient use of airport resources," DOT would have been hard pressed to disagree. Indeed, the dissent in the court's rehearing en banc decision indicates that DOT does not object to that assertion. ${ }^{178}$

The dissent claims correctly that DOT's position makes an unjustified leap of logic. Specifically, DOT moves from the conclusion that the airport cannot convert itself legally to any other use to the conclusion that pricing itself as if it could convert itself would be unlawful. Using Judge

171. Id. at 976 .

172. Id.

173. Id.

174. Id.

175. Id.

176. Id. at 978-79.

177. ZetTEL \& HoRONJEFF, supra note 105 and accompanying text.

178. City of Los Angeles v. United States Dep't of Transp., 179 F.3d 937, 940 (D.C. Cir. 1999) (Williams, J., dissenting) (noting that "[t]he Department does not contest th[e] proposition" that the City's proposed pricing results in increased efficiency), denying en banc reh' $g 165$ F.3d 972 (D.C. Cir. 1999). 
Williams's example, suppose one owns property in fee simple determinable to hold only "so long as the land is used as an airport."179 Such a grant would not compel one legally to charge historic cost for the airport's services, nor would an opportunity cost charge logically contradict the grant's terms. ${ }^{180}$ If one cares about land valuation based on fair market value because aircraft operators will receive proper economic signals, then it does not matter that the airport cannot legally convert itself to a more profitable use. The case should have centered around whether fair-market-valuation pricing provides appropriate signals, not whether it was legal for the City to convert LAX to another use.

If one sees the case as based around whether the airport's pricing structure actually provides superior economic signals, then the D.C. Circuit Court of Appeals should have required a second remand to DOT. Such a remand would have prevented DOT from rejecting a reasoned proposal by a party without some reason of its own. ${ }^{181}$ Nor would DOT have rebutted the City's argument easily. The City claimed that opportunity-cost recovery allows prices to reflect the communal cost imposed by an aircraft's use of the airport. Requiring aircraft operators to pay closer attention to the actual social costs of their decisions would align aircraft operators' self interest more closely with communal interests, when choosing among possible airports to use or whether to fly at a given time. Meanwhile, pricing that does not reflect opportunity cost will cause aircraft operators not to internalize all the costs they impose on other airport users. Because DOT did not even address the superior signaling effect of opportunity-cost valuation, the court should have required it do so.

Even if the court did not accept signaling as sufficient, there is much to quarrel with in DOT's argument that the City had no real opportunity cost. For example, that the airport could not have been legally converted immediately (given the condition of its grant agreement) does not mean that the airport has no opportunity cost as a result. Having the right to do something in the future can generate current value. Were the right to receive something in the future of no current value, then no one would be willing to forego salary today for a promise of stock options to vest in the future. But the common use of stock options in Silicon Valley indicates that one's potential to gain something in the future can have huge current value. DOT's assertion that LAX has no opportunity cost because it cannot convert the airport to other use today, is similar to one saying that his stock option has no value because he cannot exercise it now. On the contrary, its value is what one would be willing to pay for it currently on the open market (were the option freely tradable). Consider the number of people who

179. Id. at 940 (Williams, J., dissenting).

180. Id. (Williams, J., dissenting).

181. Id. at 939 (Williams, J., dissenting). 
would be willing to pay money or forego all their current salary for stock options in a new, thriving company. Returning to the airport, once the grant condition expires, the airport might be converted to a very profitable resource, and there is some positive current value given a potential future profitable use. Therefore, it is erroneous to claim that LAX has no opportunity cost because it cannot lawfully act now to convert the airport land.

In conclusion, proponents of cost-recovery methodology seek to combat the potential for inefficiently high monopoly prices by requiring airports to charge airport users only for the cost of providing airport services. Thus, cost-recovery advocates try to combine the benefits of having a monopoly supplier with subsidies to decrease the cost of air travel to aircraft operators. Indeed, to the extent that the rate base for aircraft operators includes all the social costs they impose, cost-recovery may be efficient. However, where airport prices elicit a demand beyond the airport's capacity, mere capital cost recovery is an inadequate measure of all the social costs imposed. Specifically, capital cost recovery will neglect the opportunity costs imposed by use of the airport resource.

\section{B. Federal Policy Should Encourage Peak-Period Pricing}

A second troubling aspect of DOT pricing policy is that it does not go far enough to encourage peak-period pricing. This Comment considers the importance of peak-period pricing during times of congestion. It then explores Logan Airport's attempt to establish a more efficient aircraft pricing system and DOT's skeptical response.

\section{Peak-Period Pricing as a Solution to Congestion}

A nonairport example may clarify the importance of peak-period pricing. Imagine a bridge that acts as a monopoly because it is the only way of getting from one city to the next. One early view held by economists was that the efficient price charged to users of the bridge shonld be the marginal cost (or extra cost per user) those users impose. ${ }^{182}$ Since operating, maintenance, and capital costs do not vary significantly with the rate of use, economists argued that bridge tolls should be set at zero. ${ }^{183}$ But a problem arises if setting bridge tolls at zero yields huge congestion, with traffic lined up for miles to use the free bridge. ${ }^{184}$ In such a situation, the marginal costs mentioned above do not represent all the costs imposed because they fail to capture the opportunity cost involved in using the bridge. One car's use of the bridge during a congested time displaces another car's use. ${ }^{185}$ Thus, during periods of congestion, the marginal cost of a bridge

182. Alfred E. KahN, The Economics of Regulation 87 (1970).

183. Id.

184. Id.

185. Id. at 87-88. 
crossing will not be zero, and the resulting price should be set at a level that recognizes this extra component of marginal cost.

\section{Massport PACE Case}

DOT's latest policy statement has done little to encourage peak-period charges. ${ }^{186}$ Rather, it reaffirms the position taken in response to a lawsuit concerning Logan Airport's attempt at more efficient pricing. A discussion of the Logan Airport case will highlight the skeptical view DOT has taken toward airport implementation of a more efficient pricing policy.

Boston's Logan Airport is one of 1nany United States airports that suffer serious delays. By the end of 1987, deinand for peak-hour landings under poor weather conditions far exceeded Logan's ability to handle them. ${ }^{187}$ Total annual enplanement more than doubled between 1976 and 1987 , rising from eleven million to twenty-three million passengers for 1987. ${ }^{188}$ Average demand for landing during peak hours reached one hundred operations per hour. ${ }^{189}$ Under good weather conditions, Logan could handle up to 120 operations per hour. ${ }^{190}$ However, when weather turned poor, Logan could only accommodate up to forty flights per hour. ${ }^{191}$ Common bouts of poor weather affect Logan on nearly one day out of five, causing congestion and delays for much of Logan's peak-hour traffic. ${ }^{192}$ With demand outstripping supply for airport services, Logan was rated the second most congested airport in the nation. ${ }^{193}$

Public pressure on Logan to reduce congestion heightened after two incidents in the summer of 1987. On June 25, 1987, a small plane crashed in Dorchester. ${ }^{194}$ The plane crash prompted Mayor Flynn of Boston to communicate to the FAA his desire to investigate ways to reduce small aircraft flights into Logan. Three weeks later, when another small plane was involved in a near accident, Mayor Flynn wrote a letter to David W.

186. There is some suggestion in the media that DOT is rethinking its policy on peak-period pricing. See, e.g., Randy Kennedy, U.S. Plans a Lottery Style System to Cut La Guardia Flights, N.Y. TIMEs, Nov. 9, 2000, at DI.

187. Michael Kranish, Logan Under Stress, Mounting Congestion Creates Concerns on Airport Safety, Boston GloBe, July 19, 1987, at 1.

188. Peter J. Howe, Boom at Logan Is Easing as Smaller Airports Grow, Boston GLoBe, Mar. 9, 1987, at 1; Richard H. Stewart, Logan to Hike Small-Plane Fees, Intent Is to Lessen Congestion, Boston GloBe, Aug 28, 1987, at 1.

189. Claire Barrett, Peak-Period Pricing as It Might Apply to Boston-Logan Intemational Airport

8 (Sept. 13, 1993) (unpublished manuscript, on file with the author).

190. Id. at 4.

191. Id.

192. Id.

193. Stewart, supra note 188.

194. Michael Patrick Norton, Officials Debate Plan to Hike Logan Fees: Threat to Business, Small Plane Owners Say, Boston GLoBE, Jan. 8, 1988, at 51. 
Davis, Executive Director of the Massachusetts Port Authority, calling on him "to curtail small aircraft activity at Logan."195

In March of 1988, the Massachusetts Port Authority ("Massport") introduced its new "Program for Airport Capacity Efficiency" ("PACE") at Logan. PACE represented a new system for determining aircraft landing fees. In the first stage of PACE, Logan changed landing fees from entirely weight based to a charge with two components: (1) an operations fee that was invariant with aircraft size or time of day and (2) a weight-based fee. ${ }^{196}$ The new landing fee structure was intended to be revenue neutral. That is, landing fees on some aircraft would rise while those on other aircraft would drop, thereby raising no more total revenue from aircraft than was raised in the past. ${ }^{197}$ Because the new pricing structure was not exclusively based on weight, it had the effect of lowering somewhat the landing fees paid by large commercial aircraft, while increasing those paid by smaller aircraft. ${ }^{198}$ Regional commuter aircraft's landing fees typically increased slightly while those of small jetliners remained about the same. ${ }^{199}$ For instance, under PACE the invariant fee was $\$ 91.78$ per landing with an additional charge of $\$ .5417$ per one thousand pounds of aircraft weight. ${ }^{200}$ Under this fee structure, the fee for a Beechcraft 1900 (a small private aircraft) mcreased from $\$ 25$ to $\$ 101.47$, while the fee for a Boeing 747 decreased from $\$ 823.99$ to $\$ 450.31 .^{201}$

Another feature of PACE allowed aircraft operations that Massport deemed as providing "essential air service hub operation" an exemption from the invariant fee portion of the new landing fee, and instead required payment of the pre-PACE minimum charge of twenty-five dollars per landing. ${ }^{202}$ Several regional airlines were exempted from the new PACE fees under the essential service criterion. ${ }^{203}$

\section{a. PACE: Challenged, Upheld, Overturned}

Faced with higher landing fees as a result of PACE, a group representing owners, operators, and users of small aircraft filed a complaint with the FAA claiming that PACE violated federal statutes by discriminating against small aircraft and not setting "fair and reasonable" rates. ${ }^{204}$ One month later, a different group representing general aviation and regional commuter aircraft filed suit against Massport in district court raising

195. Flynn Seeks to Reduce Logan Traffic, Boston GLOBE, July 19, 1987, at 24.

196. New England Legal Found. v. Mass. Port Auth., 883 F.2d 157, 159 (1st Cir. 1989).

197. Id.

198. Id.

199. Id.

200. Id.

201. Id.

202. Id.

203. Id.

204. Id. at 159-60. 
essentially the same arguments as those in the administrative proceeding. ${ }^{205}$ The district court refused to stay its determination pending resolution of the administrative proceeding, and thus the district court's decision was issued before the earlier filed administrative decision. ${ }^{206}$ Ruling from the bench, the district court upheld the legality of the new fee systen1, noting that Logan's congestion problem was a central issue in the dispute. ${ }^{207}$ The court maintained that the real cause of Logan's congestion was the large number of small aircraft using the airfield because of a system of landing fees that did not reflect the true cost of allowing small aircraft to land. ${ }^{208}$ The court concluded that the new fee structure under PACE "was reasonable because it had been 'fixed according to [a] uniform, fair, and practical standard ... [and was] non-excessive in comparison with the governmental benefit conferred."'209 Second, the court held that the new fees were not unjustly discriminatory because "the goal ... was to proniote a fair and reasonable landing fee which would recover from each user the cost incurred by the proprietor in providing the fees and facilities." 210

Almost five months after the district court upheld PACE, the administrative law judge ("ALJ") overseeing the FAA hearing reached the opposite conclusion, finding that PACE was unreasonable and thus contravened various federal statutes. ${ }^{211}$ On appeal, the Secretary of DOT affirmed the ALJ's decision. ${ }^{212}$ "[T] he new fees were unreasonable," the Secretary concluded, because the methodology for calculating them "was not scientifically derived." "Not3 "Not scientifically derived," according to the Secretary, meant that sniall aircraft were allocated, via landing fees, a disproportionate amount of airport costs. The Secretary believed that the heavier planes imposed higher costs on the airport and thus should pay proportionally more money than smaller aircraft. In essence, Logan's "sproblem ... (was) that it employs a traditional cost allocation approach but biases the results by the inappropriate use of opportunity costs considerations."214 Thus, DOT determined that Massport had to terminate PACE or lose federal funding. ${ }^{215}$ Massport chose the former. ${ }^{216}$

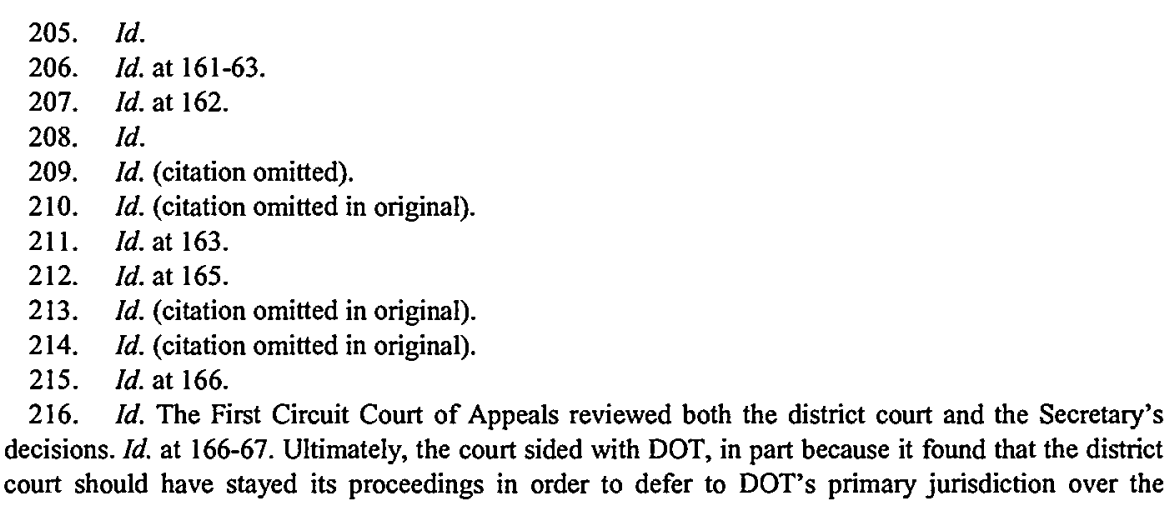


For the brief time PACE was in effect, the alleviation of congestion was impressive. Logan went froin twenty-first in on-time performance among U.S. airports to twelfth. ${ }^{217}$ This represented a gain in on-time performance from $69.5 \%$ in September of 1987 to $86.4 \%$ in September of 1988. ${ }^{218}$ After it discontinued PACE, Logan fell to twenty-seventh im on-time performance. ${ }^{219}$ Under PACE, congestion at Logan decreased in two ways. First, one-third of the general aviation traffic ${ }^{220}$ that had landed at Logan pre-PACE stopped using Logan. ${ }^{221}$ Some general aviation aircraft shifted their landings to Hanscom Field, the smaller airport nearby. Second, there was a decrease in regional commuter airline flights.22 Though the frequency of regional commuter flights decreased, the total number of passengers carried actually increased. The invariant operations portion of the landing fee was successful at inducing regional commuter airlines either to switch to larger planes, which could carry inore passengers, or to squeeze more passengers onto each flight. ${ }^{223}$ With $3.1 \%$ fewer flights, the regional commuter aircraft carried $0.6 \%$ more passengers than before. ${ }^{224}$ Thus, the total reduction in congestion came from fewer general aviation flights and more efficient regional commuter flights.

\section{b. PACE: Not Discrimination But Less Subsidization of Lighter Aircraft}

DOT concluded that Massport had discriminated against smaller aircraft operators in an attempt to drive them away from Logan. On the contrary, under PACE, Logan inerely decreased the size of the subsidy that it had previously provided to smaller aircraft at the expense of passengers in larger aircraft. ${ }^{225}$ To be sure, the operators of smaller aircraft did not claim that they were being charged more than the cost of providing landing services to other users. In fact, the prices charged to the smaller aircraft were still much lower than those charged to the major jetliners. The problem from the smaller aircraft's perspective was that Massport was not charging them sufficiently less than it was charging heavier planes. ${ }^{226}$

controversy. Id. at 171 . On the merits, the court deferred to the Secretary's determination and reversed the district court on every issue in which it reached a conclusion different from DOT. See id. at 176.

217. Richard H. Stewart, Massport Official Vows To Keep Logan Fee Hikes, Boston GLoBE, Nov. 17,1988 , at 52 .

218. Jerry Ackerman, Logan Fee Hikes Biased, Judge Says, Boston Globe, Nov. 11, 1988, at 29.

219. Laffer, supra note 5, at 3.

220. Recall that general aviation refers to privately-operated aircraft.

221. Laffer, supra note 5, at 3 .

222. Id.

223. Id.

224. Robert W. Poole, Jr., Privatizing Airports, in Reason Foundation Policy Study, at 14 (Jan. 1990) cited in $i d$.

225. Laffer, supra note 5 , at 4 .

226. Id. 
One can make a strong case from an opportunity-cost perspective that Massport was justified in requiring smaller aircraft to bear a larger landing fee than before. Though smaller aircraft typically do not impose as much wear on runways as larger jets, ${ }^{227}$ footprint pressure is influenced by more than just weight. ${ }^{228}$ Furthermore, smaller aircraft typically have slower approach speeds than jetliners, which adds to delays. ${ }^{229}$ They are more prone to wake turbulence than heavier planes, requiring landings to be spaced farther apart. ${ }^{230}$ Finally, the limited availability of special runways for smaller aircraft means that their operators may take imto account only a tiny portion of the costs of their aircraft's movement. ${ }^{231}$

The federal statutes on airport rates do not require airports to subsidize certain classes of aircraft operators more than other classes. ${ }^{232}$ Nor should federal regulations require subsidizing a class of aircraft operators when that class is comprised of less efficient aircraft. Indeed, to require airports to subsidize less efficient aircraft goes strictly agamst Executive Order 12,893, which notes that "[s]ince efficient levels of service can often best be achieved by properly pricing infrastructure, the Federal Government, through its direct investments, grants, and regulations, should promote consideration of market-based mechanisms for managing infrastructure."233

\section{Massport's Consequences for Future Peak-Pricing Proposals}

The Massport decision hinted that a properly constructed peak-time pricing system could pass muster. That PACE induced many previous Logan users to move elsewhere did not trouble the Secretary of DOT. In fact, he explicitly endorsed an airport's right to impose landing fees which encourage some aircraft to use other airports. " $[I] t$ is . . within an airport proprietor's authority to impose reasonable (, nondiscriminatory,) [sic] landing fees or other user fees, even if such fees may result in a decline in usage by a class of user or other indirect effects on users." "234

The Secretary overturned PACE largely because it mixed traditional weight-based pricing with " "the inappropriate use of opportunity costs considerations." "235 Yet in striking down PACE, the Secretary intimated support for appropriately measured opportunity-cost pricing. " $[I] f$

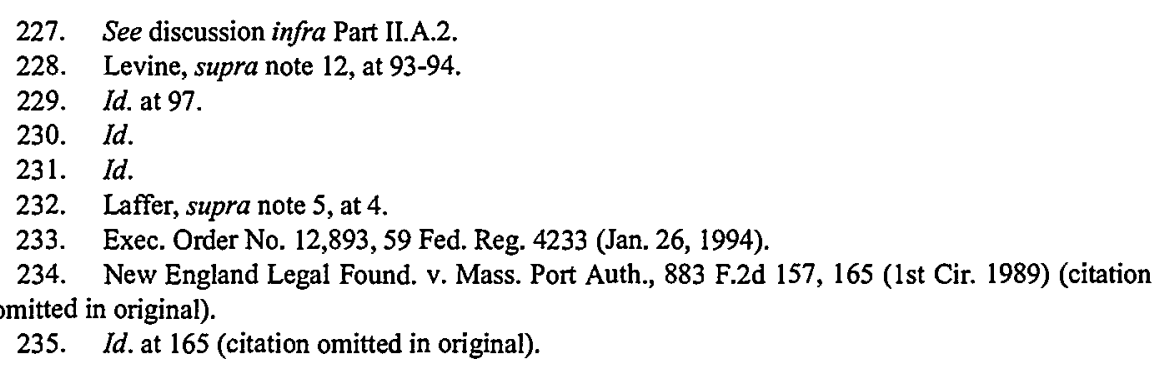


opportunity costs are to be considered at all, they 'should be treated like other costs and should not intrude upon allocating methodology.' Logan merely raised landing fees during peak hours, DOT might have upheld PACE. One might also conclude that if PACE had included a lower operations fee for nonjet users, reflecting the fact that they impose fewer costs per operation than jets, the Secretary would have upheld PACE.

Nonetheless, it is discouraging that DOT struck down a rate structure that represented a inore efficient systein. Moreover, for those congested airports considering peak-period pricing, DOT's actions in the Massport decision indicate the likely cost to any airport hoping to institute a peak-time pricing proposal. DOT should provide guidance for constructing a valid systein so that airports considering congestion pricing need not be discouraged by the uncertainty of which policies will pass muster. Otherwise, without more guidance, few airports will hazard a more efficient pricing proposal because of the huge expense of developing a more efficient policy and defending it in court.

\section{Proposed Policy Should Encourage Peak-Period Pricing}

Weight-based fees represent only one coinponent of marginal cost experienced by airports: wear on runways. ${ }^{237}$ When airports experience congestion, however, there will be an extra opportunity cost of airport use similar to that for the bridge described above. That is, each aircraft using the airport during congested hours displaces or delays other aircraft. In order to ensure that resources are allocated efficiently under conditions of congestion, aircraft operators should be charged an extra amount for their use of the airport during peak times. The extra amount charged should represent the future costs of continuing to render service during peak hours. ${ }^{238}$

\section{E. Airport Congestion Fees Should Be Set at Zero During Off-Peak Times}

Though this Comment has argued that airports should be able to recover higher fees for certain time slots, airports should not be completely free to impose charges as high as they desire. Permitting them to do so would conflict both with federal statute and public policy considerations. The problem is that many airports may be natural monopolies. ${ }^{239} \mathrm{An}$ airport left to itself may charge a rate higher than the socially optimal level. Since the main problem with current fee structures is their failure to address congestion, airports should restrict the peak-hour portion of any slot charge to

236. Id. at 166 (citation omitted in original).

237. And they represent wear imperfectly, as weight is not an accurate proxy for footprint pressure. Levine, supra note 12 , at 83-84.

238. Id. at 88-89.

239. Creager, supra note 101, at 322 . 
zero during off-peak times. ${ }^{240}$ Off-peak users ought not to pay an on-peak charge because these users make no contribution toward utilization at the peak time. ${ }^{241}$ To the extent that serving an off-peak user does not necessitate increasing the capacity of the resource, the incremental congestion cost of providing service will be zero. Since congestion costs are incurred only when more users demand airport resources than airports can supply, airport users who do not cause such congestion ought not to pay for it..$^{242}$

VI

The Proposed Pricing Structure Would Be Fairer and More EFficient than CurRent Pricing

\section{A. Incentives to Choose an Airport that Imposes the Fewest Social Costs}

If airports could include the opportunity cost of their land in their rate bases, there would be wider price differences between landing at large airports and at small airports. Consequently, those airports resting on large, valuable plots wonld have higher fees. Meanwhile, smaller, general aviation airports would have relatively lower fees (because larger airports would be able to charge proportionately more). As before, a general aviation pilot still would be free to choose between flying into a large airport like Logan and a nearby, smaller general aviation airport. But permitting airports to include a fee for the opportunity cost of their land would allow for greater pricing differentiation between the two airports. The general aviation flyer would therefore have to pay more to use Logan in order to compensate Logan for its higher opportunity cost. Whereas under the current system, aircraft choose among airports with little regard for relative demand in airport resources, including opportunity costs in slot prices would require aircraft to internalize more of the costs of supplying land for airports.

\section{B. Difference in Pricing Between Higher and Lower Value Users}

By charging aircraft operators for any congestion they cause, operators will have a greater incentive to conserve their flying during peak hours. If they value flying at a peak hour sufficiently, they can choose to fly then and pay more in slot fees. On the other hand, if they do not place such a high value on a specific time slot, they can choose to fly during offpeak hours and days. Furthermore, those consumers who do choose to pay more to fly at peak hours will find the airport much less congested than previously. Meanwhile, airlines will have more reason to ensure that

240. KAHN, supra note 182, at 89.

241. Id.

242. Id. 
on-peak flights are fuller. ${ }^{243}$ Peak-hour charges will serve to counteract current incentives, which promote scheduling of frequent short-haul routes.

\section{Fewer Tax Dollars Going Toward Airport Expansion}

Given a new system in which airports are able to raise more revenue, fewer tax dollars will be required for airport expansion. This new policy would be fairer in at least two ways. First, taxpayers who do not use airport resources will have to contribute less of their money toward airport funding. Second, it would be more equitable for those who use airports to bear a larger cost of paying for them. Since airports are prevented statutorily from diverting airport funds away from the airport, every dollar an airport makes in higher takeoff and landing slot fees would go toward maintenance, improveinent, or expansion of airport facilities. Thus, airport fees would continue to track closely those who benefit from them.

\section{Positive Environmental and Safety Consequences}

More efficient use of current airport resources would have a myriad of environmental benefits. The most obvious such advantage is that were aircraft operators to spread their use of airports more evenly throughout the day and week, there would be less demand at peak times and, as a result, less need to continue to expand airports. Airport expansion can cause a range of environmental problems from destruction of nearby ecosystems to more widespread noise. ${ }^{244}$

One of the more subtle environmental costs of the current system is the potential for greater energy use and pollution. In 1999, the FAA permitted airlines to operate some short flights (up to 500 miles) at lower altitudes than previously. ${ }^{245}$ The FAA hoped the move would alleviate congestion by allowing airlines to use less-traveled, low altitude routes. Airlines were initially hesitant to take advantage of the new routes because lower altitudes have denser air, requiring aircraft to burn more fuel. But given increasing delays, more airlines have taken advantage of this shortterm solution and have consequently been using more fuel in the process. ${ }^{246}$ Were airports to institute congestion pricing, airlines would have less need to use such environmentally unfriendly alternatives.

Another difficulty with the patchwork fixes the FAA has instituted in response to congestion problems is that many have caused their own safety problems. One such response to congestion was an increase in the nnmber

243. See supra note 16 and accompanying text (noting that airlines may schedule slots frequently because of the large competitive advantages of doing so).

244. See, e.g., Elizabeth Kristen, SFO's Proposed Runway Expansion Project and Its Impacts on the Bay 12 (May 2000) (unpublished manuscript, on file with author).

245. Alex Lyda, Airlines Changing Their Altitudes: Lower Flying Cuts Delays, But Burns More Fuel, San Diego Union \& Trib., Aug. 23, 2000, at C4.

246. Id. 
of slots that airports could allocate. For instance, a law passed in March $2000^{247}$ increased the number of slots at such airports as La Guardia, adding up to two hundred new takeoffs and landings per day. ${ }^{248}$ But the result of more slots was that La Guardia and other airports had to space flights more closely together. Though this slot tightening boosted the airport's capacity, shorter slot duration also probably increases the likelihood of accidents.

\section{E. Equities}

One argument sometimes leveled against peak-hour pricing solutions is that they would price average individuals out of the market. This fear is unlikely to come to pass for several reasons. First, even if federal regulations supported airports' attempts to collect more for certain takeoff and landing slots, ticket prices would not necessarily be affected. For example, an airline may wish to carve out a peak-hour inche inarket by keeping the same prices during on-peak as well as off-peak slots. ${ }^{249}$ But even if airlines passed on higher peak-time charges to flyers, there is reason to think that, on balance, average fiyers would benefit from the above proposal.

For those consumers who are most flexible about when to fly and what airport to fly into, this proposal would likely be beneficial. Aircraft passengers who have open schedules could arrange to fly at off-peak times or into less congested airports, thereby avoiding heightened congestion and opportunity-cost fees. For instance, a consumer who wanted to fly to Washington, D.C. would probably choose Baltimore Washington International Airport over its more crowded counterparts, National and Dulles. Indeed, were airports to institute revenue neutral pricing schemes, as Logan tried, flexible consumers who fly off peak may benefit from ticket prices that are below what they currently pay. That is, if airports maintain the same airside revenue level, higher peak-hour fees would necessitate offsetting lower off-peak fees.

Consumers who are less flexible about where and when to travel may also benefit on balance. To be sure, if airlines pass on congestion and opportunity-cost fees to consumers, then peak-time passengers would pay higher ticket prices. But these higher ticket prices would not come without their benefits. With higher prices, some passengers would be induced to fly at other times or to other airports. The remaining peak-time passengers would thus encounter fewer other passengers in the airports and their aircraft would encounter less congested takeoffs and landings.

247. Wendell H. Ford Aviation Investment and Reform Act for the 21st Century, Pub. L. No. 106181,114 Stat. 2000.

248. Kennedy, supra note 186.

249. See HARDAWAY, supra note 63, at 203. 
Who is most likely to be an inflexible flyer? Many of the least flexible aircraft passengers will be business flyers. As a consequence, those who are most capable of bearing higher ticket prices, companies, will indirectly face higher prices. Compamies may then spread the cost of higher ticket prices in the form of higher prices for the goods and services they provide. However, business flyers are not the only ones who may be unable to alter their travel plans to minimize the cost their trip imposes on others. Recreational flyers with tight schedules, especially during holidays, may be unable to find off-peak times to fly or less traveled airports to fly into. To the extent that these passengers cannot adjust their travel, they will face higher ticket prices. But for the more expensive ticket, the inflexible flyer will receive the beneflt of greater assurance of getting to his destination in a timely fashion.

Evidence from Logan Airport indicates that those who are most likely to face the largest increase in slot fees are general aviation aircraft operators. Unlike large aircraft that can spread the higher fees among many passengers, general aviation aircraft tend to be small planes carrying few passengers. As a consequence, any additional slot fees will be disproportionately higher for a passenger in a general aviation aircraft than in a larger airline aircraft. At first glance, it may seem unfair for general aviation passengers to pay higher prices. But recall that general aviation craft, because of fewer seats, are much less efficient at moving people than are larger aircraft. General aviation aircraft also may impose higher congestion costs given that they often take longer than larger aircraft to take off and land. Though it may not seem fair to charge general aviation more than the costs they impose on the airport, it is fair to require them to pay a larger portion of the costs they imcur. Put another way, at congested airports less efficient general aviation aircraft should stop receiving such a large subsidy in the form of below-cost slot fees. ${ }^{250}$

\section{CONCLUSION}

Congestion of major United States airports will not dissipate without significant progress in either expanding airports, inducing more efficient use of current resources, or both. Though there is widespread political support for airport expansion, support for more efficient pricing has been harder to find. New pricing proposals face political opposition from a strong airline lobby and are backed by a weaker, more decentralized airport

250. It is important to note that the general aviation aircraft would not pay more than its airline counterpart flying at the same time into the same airport. Rather, under the Comment's proposal, the general aviation aircraft would pay more to fly into an expensive, congested airport than it currently does. 
lobby. Also, given that many congressmen have pilot licenses ${ }^{251}$ and many rich businessmen use general aviation aircraft, consumers will have to exert strong political pressure before the federal government or Congress support pricing changes leading to higher general aviation slot fees. ${ }^{252}$ Meanwhile, severe overcrowding problems may lead airports to attempt the same sorts of local solutions as airport operators at Logan and LAX tried.

This Comment has argued that new DOT policy would be an inexpensive and effective alternative to investing more in airport resources. If DOT encouraged airports to charge for the opportunity cost of their land and urged them to charge more for congestion costs, airports could move toward a more economically rational approach. Meanwhile, failure to realize and address the wasteful incentives created by current DOT policy will leave Americans stuck on the ground and in the air with ample time to ponder the consequences of airport congestion.

251. Ed Carson, O Canada! Our Northern Neighbor Privatizes Its Air Traffic Control System But Privatization Plans Are Still Circling Washington, REAson, Apr. 1996, at 23 (noting that many private pilots are affluent and a number are congressmen).

252. The situation has gotten so bad that the federal government has made rumblings about market-based solutions to congestion problems. See Kennedy, supra note 186. 